\title{
The correction of foam glass composition based on its principal parameters
}

\author{
Dmitry Safonchik ${ }^{1}$, Svetlana Maksimovich ${ }^{1}$ \\ ${ }^{1}$ Grodno State University named after Yanka Kupala, Grodno, RB.
}

\begin{abstract}
Annotation. Thermal insulation materials are the main link in solving the problem of enclosing constructions energy efficiency. The number of heat insulators is relatively low, that's why it is important to develop new insulators that would be better than the existing ones in their characteristics. Such heat-insulating material as foam glass is known, but it is practically not applied, despite the fact that it possesses high heatinsulating and mechanical characteristics, it is non-combustible, durable and environmentally friendly. All the advantages of foam glass are inferior to one drawback. It is the high cost price of this material. If the cost price of foam glass was reduced and its main characteristics were at the same level, foam glass would take a leading position among other heatinsulating materials. The article presents some information about the development of foam glass, in which dolomite flour is used as a foaming agent. The material proposed by the authors has a density of about $200 \mathrm{~kg} /$ $\mathrm{m} 3$, water absorption of $25 \%$. The material is manufactured at maximum foaming temperature of $750{ }^{\circ} \mathrm{C}$.
\end{abstract}

\section{Introduction}

The high cost of energy resources has led to the fact that the energy efficiency problem has become the most important one for most countries of the world. As a result, many countries have to develop energy efficiency programs. [1]. Energy consumption reducing is possible in different ways, for example, by reducing the thermal conductivity of enclosing structures while using modern thermal insulation materials [2].

Currently, the range of widely used thermal insulation materials is quite limited. These are mainly expanded polystyrene and mineral wool [3]. These materials, being good heat insulators, have a number of disadvantages: environmental unfriendliness (both expanded polystyrene and mineral wool), high water absorption, flammability and low strength (expanded polystyrene) [4].

The analysis of existing modern heat-insulating materials showed that such material as foam glass can be attributed to the most effective one. Foam glass practically has no drawbacks, but the material is practically not used due to its high cost [5]. The competitiveness of foam glass can be increased by reducing its cost price while maintaining the main characteristics [6]. 
One of the ways of reducing the foam glass cost price is using the secondary resources (cullet) and carbonate blowing agents from local raw materials (dolomite flour) as raw materials.

The characteristics of foam glass which is obtained by applying a carbonate blowing agent (dolomite flour) are not satisfactory enough, which is connected with high average density (300 kg / m3), compared with traditional foam glass (less than $200 \mathrm{~kg} / \mathrm{m} 3$ ), and an increased value of water absorption (25-30\%) [7].

Carbonate blowing agents, unlike carbon ones, are not surfactants, and are characterized by significant affinity for glass melting and cannot have a stabilizing effect on glass foam. These blowing agents reduce the foaming temperature by $70-100 \mathrm{C}$, but the foam glass becomes spongy, with perforated shells of gas cells. It is considered that it is not possible to obtain foam glass characterized by low water absorption (less than 10\%) and density using carbonate blowing agents [8].

Hence it follows that to improve the characteristics of the obtained foam glass, it is necessary to introduce additional components that would contribute to the intensification of the gas evolving process and the formation of a uniformly distributed pore structure. The change of temperature-time regime with foaming temperature increasing and the holding time will lead to a decrease in the average density only due to the formation of large pores. As a result the material will lose its heat-protecting properties.

Water absorption reducing is possible by introducing additional components into the charge composition [9]. The introducing of kaolin reduces the water absorption of foam glass due to the formation of insoluble silicates or hydrosilicates in an alkaline solution. Glycerin is a plasticizer and intensifier of the drying process, increases the silicate modulus of water glass, and also contributes to small pores formation[10].

Therefore, it is advisable also to add glycerin to the charge, which leads to gas evolving and the formation of small pores in the bulk of the material, and water glass, which in small amounts helps to reduce water absorption. In addition, water glass leads to additional foaming [11]. [12] It is mentioned in the work that the introduction of water glass reduces the viscosity of the molten glass in the temperature range of $740-840^{\circ} \mathrm{C}$ by $2.5-4$ times that facilitates the foaming process [13].

Thus, it can be assumed that foam glass obtained with the use of a carbonate blowing agent can be obtained with a density of less than $200 \mathrm{~kg} / \mathrm{m} 3$ and a water absorption of less than $30 \%$ only with the use of more additions. Such foam glass will reduce the cost in comparison with traditional foam glass.

\section{Charge preparation method}

Ground glass was mixed with a dolomite blowing agent, glycerin, and liquid glass to prepare the charge [14-16]. After mixing water was added to the mixture in an amount of $0.25 \pm 0.05$ parts by weight. from the dry matter mass of the raw mixture.

The optimal water amount added to the charge has been determined experimentally. The results are shown in Figure 1. 


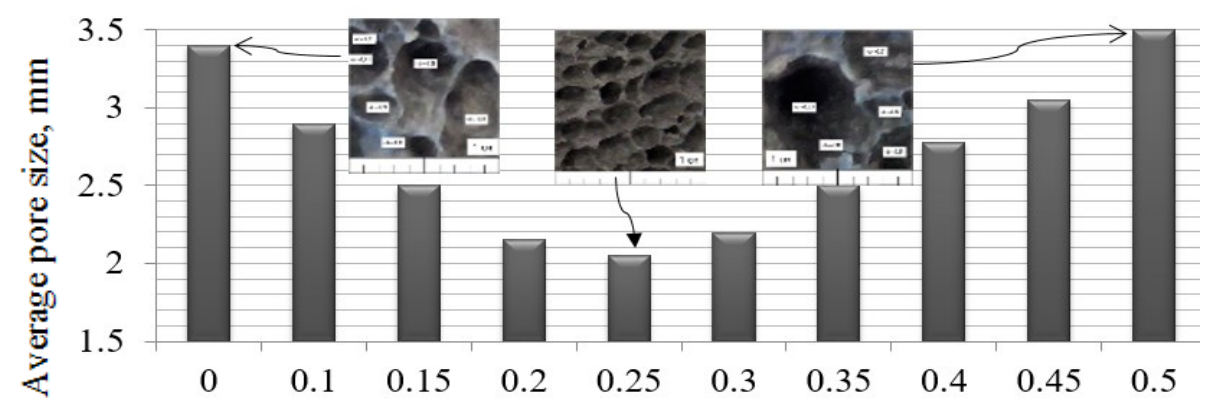

Amount of water

Figure 1 - Dependence of the foam glass pore size on the amount of the added water

The prepared charge was put into special moulds, the filling of which by volume was $30-50 \%$. Then the moulds were placed into an electric muffle furnace preheated to the settled temperature.

\section{Foaming}

The foam glass production was carried out by using one-stage powder technology [6]. The powder method production of foam glass is the most widespread nowadays 17].

The foaming was carried out in a laboratory muffle furnace SNOL 7.2-1100 with a useful volume of 7.2 liters and 4 sides heating[18].

Based on the analysis of various literary sources, it was determined that the duration of the foaming mixture heating varies greatly (from 15 minutes to 2-3 hours) [19]. The process of heat treatment of the foam glass batch should be carried out on one hand at a temperature not lower than the glass melting temperature, on the other hand - the temperature should be sufficient to activate the process of the blowing agent decomposition[20].

Therefore, during the experiment, the temperature-time regime was adjusted depending on the type and amount of raw materials. Annealing of foam glass blocks was carried out with spontaneous cooling of a muffle furnace for 24 hours, which guaranteed smooth cooling of the material throughout the entire volume without the occurrence of internal stresses. After removing the samples from the moulds, they were given the specified dimensions by trimming the edges.

\section{Results and their discussion}

At the first stage of the work the optimal amount of auxiliary substances of the foam glass charge obtained by using a carbonate blowing agent was determined (Table 1).

Table 1 - The influence of glycerin on the main characteristics of foam glass

\begin{tabular}{|c|c|c|}
\hline Glycerin, \% & Avg. density, g / cm3 & Water absorption, $\%$ \\
\hline 0,25 & 0,298 & 31,8 \\
\hline 0,5 & 0,271 & 33,1 \\
\hline 0,75 & 0,223 & 35,6 \\
\hline 1 & 0,195 & 37,8 \\
\hline 1,25 & 0,191 & 39,7 \\
\hline 1,5 & 0,193 & 38,2 \\
\hline
\end{tabular}


According to the data in Table 1, it can be seen that glycerin contributes to a decrease in the average density of the material. The achievement of an average density value of less than $200 \mathrm{~kg} / \mathrm{m} 3$ is possible with the addition of glycerin in $1 \%$ amount. The changes in the foam glass structure with glycerin and free from it are shown in Figure 2.

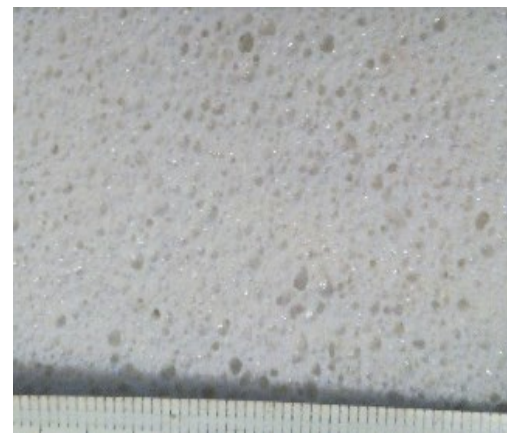

a) $\rho=300 \mathrm{~kg} / \mathrm{m} 3$

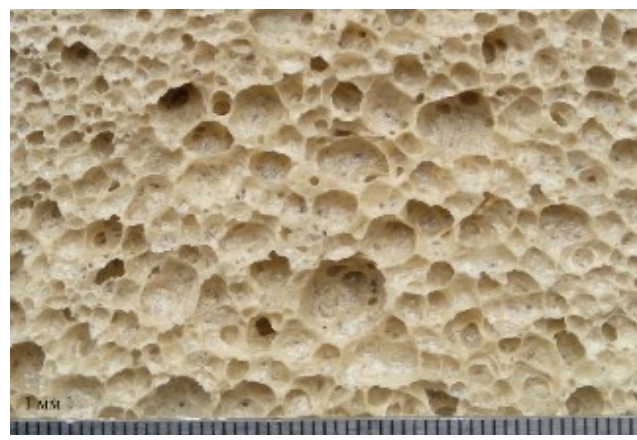

b) $\rho=195 \mathrm{~kg} / \mathrm{m} 3$

Figure 2 - The structure of foam glass: a) with $1 \%$ of dolomite flour; b) with dolomite flour $1 \%$ and glycerin $1 \%$

The experimental results indicate that at glycerol consumption of $0.75 \%$ or more, the density of the foam glass is significantly reduced compared to the initial one. But at the same time, large pores $(4-5 \mathrm{~mm})$ appear in the structure of the material, which indicates that the foaming temperature is higher than the required one. Therefore, it was necessary to clarify the temperature at which the formation of uniformly sized, uniformly distributed pore cells would occur.

With the introduction of various amounts of glycerin $(0.75 \% ; 1.0 \% ; 1.25 \%)$, the foaming temperature was gradually reduced into the charge. The experimental results are shown in Figures 3 and 4.

At a foaming temperature of $770 \pm 10^{\circ} \mathrm{C}$, the optimal consumption of glycerin can be considered an amount of $0.75-1 \%$. The specified temperature contributes to the formation of more evenly distributed pores than at temperature above $830^{\circ} \mathrm{C}$.

At the second stage of the work, the optimal amount of liquid glass was determined (table 2).

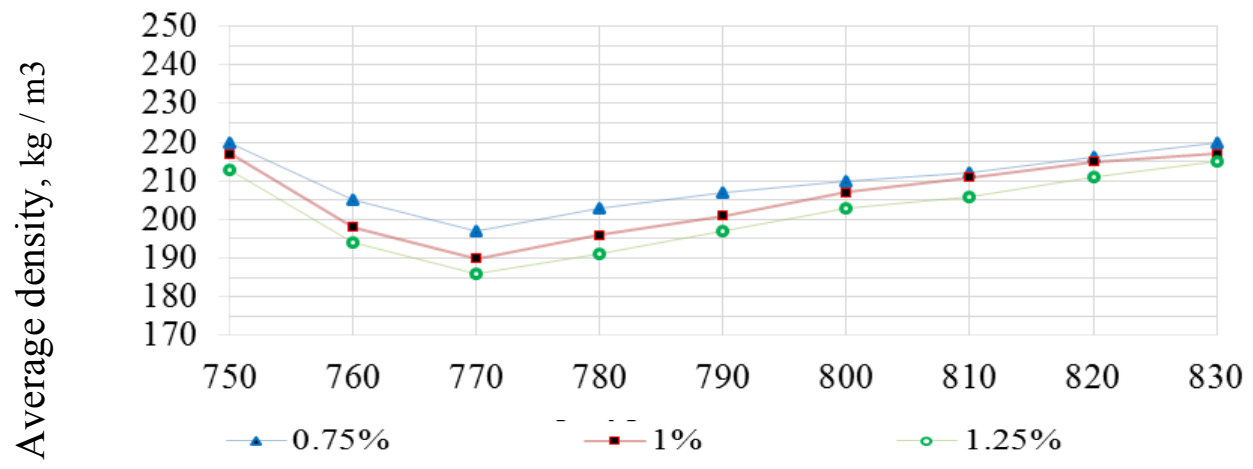

Foaming temperature, ${ }^{\circ} \mathrm{C}$

Figure 3 - Dependence of the foaming temperature on the glycerin content 


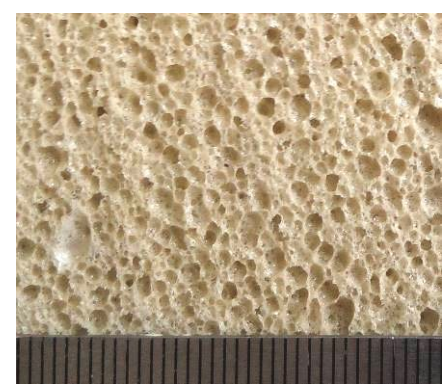

a) $\rho=198 \mathrm{~kg} / \mathrm{m} 3$

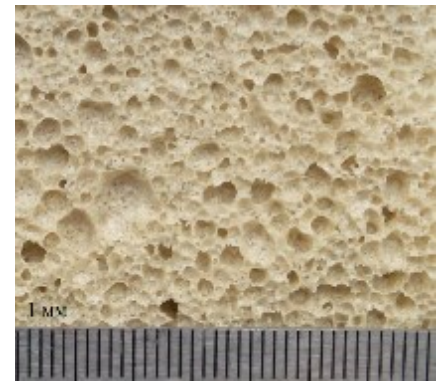

b) $\rho=191 \mathrm{~kg} / \mathrm{m} 3$

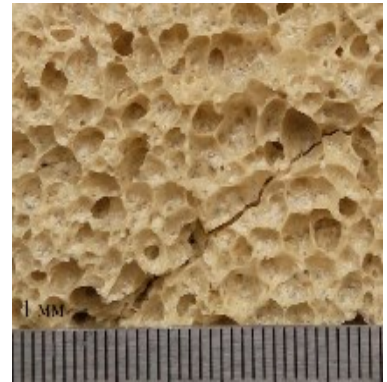

c) $\rho=185 \mathrm{~kg} / \mathrm{m} 3$

Figure 4 - The pore structure of the material at a foaming temperature of $770{ }^{\circ} \mathrm{C}:$ a) $0.75 \%$ glycerin; b) $1.0 \%$ glycerin c) $1.25 \%$ glycerin

Table 2 - The influence of liquid glass on the foam glass characteristics.

\begin{tabular}{|c|c|c|}
\hline Liquid glass $\mathrm{Na}_{2} \mathrm{O}\left(\mathrm{SiO}_{2}\right)_{\mathrm{n}}, \%$ & Avg. density, $\mathrm{g} / \mathrm{cm} 3$ & Water absorption, $\%$ \\
\hline 1 & 0,333 & 9,6 \\
\hline 2 & 0,320 & 8,5 \\
\hline 2,5 & 0,315 & 8 \\
\hline 3 & 0,300 & 6 \\
\hline 3,5 & 0,310 & 6 \\
\hline
\end{tabular}

The addition of liquid glass made it possible to reduce the water absorption of the foam glass prepared by using a carbonate blowing agent. So the introduction of liquid glass in an amount of $1.0 \%$ led to a decrease in water absorption to $10 \%$ (for foam glass without this additive, $\mathrm{W}=30-40 \%$ ). By changing the foaming temperature of the samples with the addition of liquid glass in an amount of $1 \%$, photographs of the structure of the foam glass samples were taken (Figure 5).

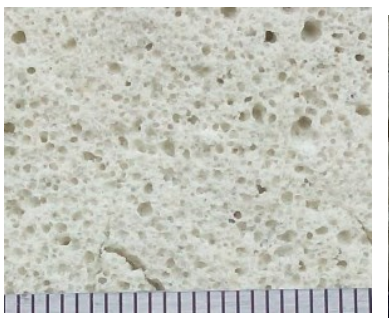

a) $\rho=354 \mathrm{~kg} / \mathrm{m} 3$

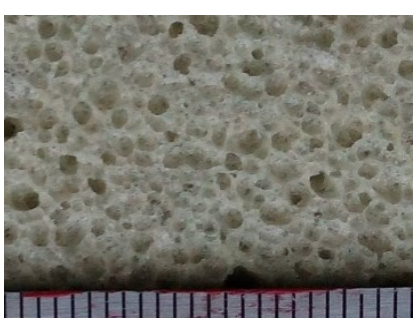

b) $\rho=304 \mathrm{~kg} / \mathrm{m} 3$

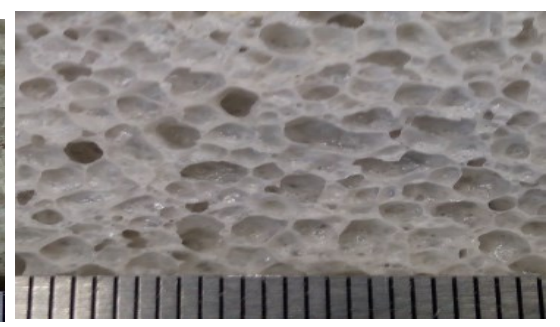

c) $\rho=296 \mathrm{~kg} / \mathrm{m} 3$

Figure 5 - The pore structure of the material with the addition of $1 \%$ of liquid glass at the foaming temperature of: a) $790{ }^{\circ} \mathrm{C}$; b) $800^{\circ} \mathrm{C}$; c) $810{ }^{\circ} \mathrm{C}$

It was concluded that the optimal value of the foam glass foaming temperature with the addition of liquid glass in an amount of $1 \%$ is $800{ }^{\circ} \mathrm{C}$, which is $30^{\circ} \mathrm{C}$ lower than the initial one. At the same time, the water absorption rate remains, the value of which does not exceed $10 \%$.

In order to optimize the foam glass composition, we combined the materials that have a positive effect on its structure separately, and conducted the experiment to study the main characteristics of the foam glass of the following composition: cullet - 95.75\%; dolomite flour - $1 \%$; granite screenings - $1.5 \%$; glycerin - $0.75 \%$; liquid glass - $1 \%$ (table 3 ). 
Table 3 - Characteristics of foam glass with an optimized composition

\begin{tabular}{|c|c|c|c|}
\hline $\begin{array}{c}\text { Liquid glass } \\
\text { / Glycerin, } \%\end{array}$ & $\begin{array}{c}\text { Foaming } \\
\text { temperature, }{ }^{\circ} \mathrm{C}\end{array}$ & Avg. density, g/ cm3 & $\begin{array}{c}\text { Water } \\
\text { absorption, } \%\end{array}$ \\
\hline \multirow{3}{*}{$1 / 0,75$} & 770 & 0,170 (heterogeneous structure) & 55 \\
\cline { 2 - 4 } & 760 & 0,194 & 40 \\
\cline { 2 - 4 } & 750 & 0,198 & 25 \\
\cline { 2 - 4 } & 740 & 0,294 & 7 \\
\hline
\end{tabular}

Practical results have shown that it is possible to obtain foam glass on a carbonate (dolomite flour) gas generator with a density of less than $200 \mathrm{~kg} / \mathrm{m} 3$ at a foaming temperature of $750{ }^{\circ} \mathrm{C}$ using glycerin in an amount of $1 \%$, but the water absorption is about $38 \%$. The use of liquid glass in an amount of $1 \%$ made it possible to reduce water absorption to $25 \%$. It is also possible to reduce water absorption to $7 \%$, but the average density will increase to $300 \mathrm{~kg} / \mathrm{m} 3$.

\section{Conclusions}

1. It is necessary to expand the range of heat-insulating materials to reduce energy consumption. Foam glass can become one of the promising heat insulators, if the energy consumption for its manufacture is reduced while maintaining the original characteristics.

2. Grodno State University has developed a technology of producing foam glass based on a dolomite blowing agent, which made it possible to obtain material with a density of up to $200 \mathrm{~kg} / \mathrm{m} 3$ at a maximum foaming temperature of $750^{\circ} \mathrm{C}$ with water absorption of $25 \%$.

3. The work presented in the article is not completed yet, since it is necessary to optimize the composition for reducing the amount of water absorption, while maintaining the average density at the level of $200 \mathrm{~kg} / \mathrm{m} 3$. It is also necessary to adjust the thermal regime of foamed glass foaming to optimize the pore structure.

\section{References}

1. Maksimovich, S.V. To the question of the expediency of foam glass using in the building structures insulation/ S.V. Maksimovich // Materials of the IV International Scientific and Practical Conference "Quality. Technologies. Innovations ". - Novosibirsk: NGASU (Sibstrin), 2021 .-- S. 185-191.

2. Savinov, M.Yu. Variability of approaches to the calculation of the effective thermal conductivity of foam glass / M.Yu. Savinov // New science: current state and ways of development. - 2017. - vol. 2, no. 3. - S. 188-192.

3. Igokhina, E.O. Comparative analysis of the most popular heaters in construction / E.O. Igokhina // Ecology and Construction. - 2016. - No. 1. - S. 7-11.

4. Fedosov, S.V. Basic principles of the technology of obtaining heat-insulating foam glass, approaches to modeling / S.V. Fedosov, M.O. Bakanov, S.N. Nikishov // Scientific-practical conference dedicated to the 85th anniversary of the Honored Scientist of the Russian Federation, Academician of the RAASN, Doctor of Technical Sciences, Bazhenov Yuri Mikhailovich. - Belgorod, 2015. - P. 690-699.

5. Stepanova, M.N. Development of the composition and technology of a heatinsulating composite based on foam glass with a protective and decorative coating: Author's abstract. ... Cand. of tech. Sciences 05.17.11. / M.N. Stepanova; Belgorod State technol. University named after V.G. Shukhov. - Belgorod, 2009 .-- 17 p.

6. Safonchik, D.I. Foam glass derived by using granite wastes / D.I. Safonchik // Education. Transport. Innovation. Construction. Collection of materials of the II National 
Scientific and Practical Conference. April 18-19, 2019. - Omsk, SibADI 2019. - pp. 440444.

7. Heat-insulating materials for buildings and structures. Foam glass products (CG). Specifications: GOST EN 13167-2015. - Introduction. 01.08.2016. - Minsk: State Committee for Standartization of the Republic of Belarus, 2015 .-- $42 \mathrm{p}$.

8. The method of production of heat-insulating block foam glass: Pat.RF, V.I. Naumov, Yu.I. Naumov. - No. 2237031. - Publ. 05/12/03

9. The charge for foam glass obtaining: pat.RF, IPC C 03 C 11/00, / L.G. Fedyaeva, A.V. Blagov, A.V. Fedoseev. - No. 2540719. - Publ. 02/10/15.

10. Foam glass: Patent 46335 GDR, MKI S 03 S 11/00.

11. Semeinykh, NS The analysis of various raw materials using in the production of granulated foam glass / NS Semeinykh, GV Sopegin // Bulletin of the Perm National Research Polytechnic University. Construction and architecture. - 2017. - T. 8, No. 1. - P. $60-74$.

12. The method of the foam obtaining. A.S. USSR N 1571014. MKI C 03 C 11/00 / A. A. Grigoryan, G.S. Melkonyan, A.A. Sargsyan, A.S. Grigoryan. - Publ. 15.06.90.

13. Limestone flour (dolomite). Specifications: GOST 14050-93. - Introduction. 01.01.1995. - Moscow: Committee of the Russian Federation for standardization, metrology and certification, 1993. - $12 \mathrm{p}$.

14. Reagents. Glycerol. Specifications: GOST 6259-75. - Introduction. 1976.01.01. - Moscow: IPK publishing house of standards, 1976. - 8 p.

15. Liquid sodium glass. Specifications: GOST 13078-81. - Introduction. 1982.01.01. - Moscow: Standartinform, 2005 - 15 p.

16. Demidovich, B.K. Demidovich - Minsk: Science and Technology, 1975 .-- 248 p.

17. Fedotov, S.V. Variability of approaches to mathematical modeling of foam glass mixture heat treatment. / Fedotov, M.O. Bakanov, S.N. Nikishov // Bulletin of the Belgorod State Technological University. V.G. Shukhov. -2017. - No. 11. - P. 110-116

18. Proskuryakov, A.N. Measuring of glass melts viscosity using a vibrating viscometer / A.N. Proskuryakov, M.B. Remizov, S.A. Dubkov // Polar Lights 2005. Nuclear Future: Security, Economics and Law: Collection of Abstracts of the VIII International Youth Scientific Conference. - SPb., 2005.

19. Safonchik, D.I. Technological aspects of foam glass production / D.I. Safonchik, M.V. Lyshchik // Architectural and construction complex: Problems, prospects, innovations. Electronic collection of articles of the international scientific conference dedicated to the 50th anniversary of Polotsk State University on April 5-6, 2018. Novopolotsk, 2018. - pp. 256-259.

20. Fedosov, S.V. Foam glass: production features, modelling of heat transfer and gas formation processes / S.V. Fedosov, M.O. Bakanov // Academia. Architecture and construction. - 2015. - No. 1. - P. 108-113. 